\title{
URINARY EXCRETION OF PROLYLHYDROXYPROLINE IN RHEUMATIC DISEASES*
}

\author{
BY \\ HARRY BIENENSTOCK \\ From the Department of Rheumatic Diseases, Hospital for Special Surgery, New York Hospital, \\ Cornell Medical Center, New York, N.Y., \\ and the Department of Medical Services, Coney Island Hospital affiliated with Maimonides Medical Center, \\ Brooklyn, New York \\ AND \\ ANDRÉ C. KIBRICK \\ Fro $n$ Institute for Muscle Disease, New York, N.Y.
}

The urinary excretion of hydroxyproline has been reported to be raised in growing children (Ziff, Kibrick, Dresner, and Gribetz, 1956), and in the following pathological conditions:

(1) Acromegaly (Benoit, Theil, and Watten, 1963).

(2) Paget's disease of bone (Benoit and others, 1963).

(3) Hyperthyroidism (Sjoerdsma, Udenfriend, Keiser, and LeRoy, 1965).

(4) Marfan's syndrome (Sjoerdsma, Davidson, Udenfriend, and Mitoma, 1958).

(5) Hyperparathyroidism (Benoit and others, 1963; Laitinen, Nikkilä, and Kivirikko, 1966).

(6) Primary and metastatic bone tumours (Hosley, Taft, Olson, Gates, and Beebe, 1966; Bonadonna, Merlino, Nyers, and Sonenberg, 1966).

Previous reports have indicated that most patients with rheumatoid arthritis and other diffuse connective tissue disorders excrete normal amounts of hydroxyproline (Smiley and Ziff, 1964). To find out any differences in urinary metabolites of collagen containing hydroxyproline that would indicate that collagen is degraded by alternative routes, we have studied the urinary excretion of prolylhydroxyproline (a dipeptide containing over 50 per cent. of the total hydroxyproline normally excreted) in a group of patients with rheumatic diseases.

*This investigation was supported by Public Health Service Grant AM 06706 from the National Institute of Arthritis and Metabolic Diseases.

\section{Method}

Forty patients with rheumatic disease were studied. Thirty had classical or definite rheumatoid arthritis (American Rheumatism Association Criteria) and ten had a diffuse connective tissue disease: scleroderma (3), systemic lupus erythematosus (2), polymyositis (2), and ankylosing spondylitis, psoriatic arthropathy, and Still's disease (1 each). One patient who was previously known to have hyperhydroxyprolinaemia $\dagger$ was also studied. Seventeen healthy persons ranging in age from 19 to 55 years served as controls.

The subjects were placed on a collagen-free diet fog 3 days. On the third day, one accurate 24-hour uring was collected and a portion was acidified to about $\mathrm{pH}$. and immediately stored in a freezer at $-20^{\circ} \mathrm{C}$. unti analysed. Total hydroxyproline was determined by the method of Prockop and Udenfriend, (1960) whereby we recover about 95 per cent. of added hydroxyproline. Prolylhydroxyproline was determined in a sample of $80 \mathrm{ml}$. of the acidified urine by an involved chemical method employing the principle of isotope dilution after addition of synthetic ${ }^{14} \mathrm{C}$ prolylhydroxyproline. The original method (Kibrick, Hashiro, Schutz, Walters, and Milhorat, 1964) depended on autoradiography at each step in order to locate the radioactive compound on the papers used for electrophoresis and for chromatography. This method has now been improved by the development of a scanning device (Kibrick, Power, Sevendal, and Milhorat, in press) with which radioactive material can be located on the large sheets of paper, thereby avoiding the time-consuming autoradiography.

$\uparrow \mathrm{We}$ are indebted to Dr. J. W. T. Seakins for urine from this patient.

TABLE I

AVERAGE DAILY EXCRETION OF HYDROXYPROLINE AND PROLYLHYDROXYPROLINE IN SEVENTEEN NORMAL ADULTS

\begin{tabular}{|c|c|c|c|c|c|}
\hline \multirow{3}{*}{$\begin{array}{c}\text { Mean } \\
\text { Age } \\
\text { (yrs) }\end{array}$} & \multirow{3}{*}{$\begin{array}{l}\text { Sex } \\
\mathbf{M} / \mathbf{F}\end{array}$} & \multicolumn{3}{|c|}{ Hydroxyproline } & \multirow{3}{*}{$\begin{array}{c}\text { Prolylhydroxy- } \\
\text { proline } \\
\text { (mg./24 hrs) }\end{array}$} \\
\hline & & \multirow{2}{*}{$\begin{array}{c}\text { Total } \\
\text { (mg./24 hrs) }\end{array}$} & \multicolumn{2}{|c|}{ as Dipeptide } & \\
\hline & & & (mg./24 hrs) & per cent. of Total & \\
\hline $27 \cdot 7$ & $5 / 12$ & $25 \cdot 8$ & $13 \cdot 8$ & $57 \cdot 5$ & $24 \cdot 1$ \\
\hline
\end{tabular}


Results

The results obtained in the seventeen normal adults (Table I) gave an average daily total hydroxyproline excretion of $25.8 \mathrm{mg}$. (range 10.8 to $56 \cdot 2$ ); the percentage of the total hydroxyproline excreted as the dipeptide averaged $57 \cdot 7$ per cent. (range $39 \cdot 2$ to $81 \cdot 7$ ).

The results in the thirty patients with rheumatoid arthritis (Table II), ten with various diffuse connective tissue diseases, and one with hyperhydroxyprolinaemia (Table III), showed an average total hydroxyproline excretion of $30.3 \mathrm{mg}$. $/ 24 \mathrm{hrs}$ (range $11 \cdot 1$ to $73 \cdot 3$ ) in the rheumatoid patients and $38 \cdot 2$ mg./24 hrs (range 10.3 to 154 ) in those with diffuse connective tissue disease. The former excreted an average of 48.8 per cent. (range 35.9 to $73 \cdot 3$ ) as dipeptide, and the latter 53.9 per cent. (range 40.4 to $59 \cdot 8$ ).

The patient with previously known hyperhydroxyprolinaemia excreted $1,488 \mathrm{mg} . / 24 \mathrm{hrs}$ of total hydroxyproline (62 per cent. prolylhydroxyproline).

\section{Discussion}

It is evident that the percentages of hydroxyproline excreted as prolylhydroxyproline are in the same range in patients with rheumatic diseases and in controls. This similarity is especially significant in the case of the one patient (an 11-year-old boy) with hyperhydroxyprolinaemia in whom the total hydroxyproline excretion was 50 to 100 times that of normal. This is consistent with other studies that have shown that the percentage of total urinary hydroxyproline excreted as prolylhydroxyproline is essentially the same in patients with muscular dystrophy before and during the prolonged administration of prednisone, which reduced the total urinary hydroxyproline by as much as 70 to 80 per cent. (Kibrick, Power, Sevendal, and Milhorat, 1967). The finding that the proportion of urinary hydroxyproline in the form of prolylhydroxyproline varies in the same range of 40 to 80 per cent. would suggest that patients with rheumatic diseases metabolize collagen in a normal manner

TABLE II

AVERAGE DAILY EXCRETION OF HYDROXYPROLINE AND PROLYLHYDROXYPROLINE IN THIRTY PATIENTS WITH RHEUMATOID ARTHRITIS

\begin{tabular}{|c|c|c|c|c|c|}
\hline \multirow{3}{*}{$\begin{array}{c}\text { Mean } \\
\text { Age } \\
\text { (yrs) }\end{array}$} & \multirow{3}{*}{$\begin{array}{l}\text { Sex } \\
\mathbf{M} / \mathbf{F}\end{array}$} & \multicolumn{3}{|c|}{ Hydroxyproline } & \multirow{3}{*}{$\begin{array}{c}\text { Prolylhydroxy- } \\
\text { proline } \\
\text { (mg./24 hrs) }\end{array}$} \\
\hline & & \multirow{2}{*}{$\begin{array}{c}\text { Total } \\
\text { (mg./24 hrs) }\end{array}$} & \multicolumn{2}{|c|}{ as Dipeptide } & \\
\hline & & & (mg./24 hrs) & per cent. of Total & \\
\hline 54 & $7 / 23$ & $30 \cdot 3$ & $14 \cdot 8$ & $48 \cdot 8$ & $25 \cdot 7$ \\
\hline
\end{tabular}

TTABLE III

DAILY EXCRETION OF HYDROXYPROLINE AND PROLYLHYDROXYPROLINE IN TEN PATIENTS WITH DIFFUSE CONNECTIVE TISSUE DISEASE AND ONE WITH HYPERHYDROXYPROLINAEMIA

\begin{tabular}{|c|c|c|c|c|c|c|c|}
\hline \multirow{3}{*}{ Diagnosis } & \multirow{3}{*}{ Case No. } & \multirow{3}{*}{ Age } & \multirow{3}{*}{ Sex } & \multicolumn{3}{|c|}{ Hydroxyproline } & \multirow{3}{*}{$\begin{array}{c}\text { Prolylhydroxy } \\
\text { proline } \\
\text { (mg./24 hrs) }\end{array}$} \\
\hline & & & & \multirow{2}{*}{$\begin{array}{c}\text { Total } \\
\text { (mg./24 hrs) }\end{array}$} & \multicolumn{2}{|c|}{ As Dipeptide } & \\
\hline & & & & & (mg./24 hrs) & per cent. of Total & \\
\hline $\begin{array}{l}\text { Still's } \\
\text { Disease }\end{array}$ & 1 & 16 & $\mathbf{F}$ & $34 \cdot 7$ & $14 \cdot 7$ & $42 \cdot 5$ & $25 \cdot 6$ \\
\hline $\begin{array}{l}\text { Rheumatoid } \\
\text { Arthritis } \\
\text { and Psoriasis }\end{array}$ & 2 & 37 & $\mathbf{M}$ & $42 \cdot 2$ & $22 \cdot 3$ & $53 \cdot 0$ & $38 \cdot 8$ \\
\hline $\begin{array}{l}\text { Ankylosing } \\
\text { Spondylitis }\end{array}$ & 3 & 34 & $\mathbf{M}$ & $27 \cdot 0$ & $15 \cdot 5$ & $57 \cdot 5$ & $27 \cdot 2$ \\
\hline $\begin{array}{l}\text { Systemic } \\
\text { Lupus } \\
\text { Erythematosus }\end{array}$ & $\begin{array}{l}4 \\
5\end{array}$ & $\begin{array}{l}38 \\
40\end{array}$ & $\begin{array}{l}\mathbf{F} \\
\mathbf{F}\end{array}$ & $\begin{array}{l}18 \cdot 5 \\
10 \cdot 3\end{array}$ & $\begin{array}{r}10 \cdot 1 \\
5 \cdot 9\end{array}$ & $\begin{array}{l}54 \cdot 5 \\
56 \cdot 7\end{array}$ & $\begin{array}{l}17 \cdot 6 \\
10 \cdot 2\end{array}$ \\
\hline $\begin{array}{l}\text { Dermato- } \\
\text { myositis }\end{array}$ & $\begin{array}{l}6 \\
7\end{array}$ & $\begin{array}{l}60 \\
42\end{array}$ & $\begin{array}{l}\mathbf{F} \\
\mathbf{M}\end{array}$ & $\begin{array}{r}21 \cdot 0 \\
154 \cdot 7\end{array}$ & $\begin{array}{l}12 \cdot 5 \\
92 \cdot 2\end{array}$ & $\begin{array}{l}58 \cdot 8 \\
59 \cdot 4\end{array}$ & $\begin{array}{r}21 \cdot 9 \\
161 \cdot 0\end{array}$ \\
\hline Scleroderma & $\begin{array}{r}8 \\
9 \\
10\end{array}$ & $\begin{array}{l}38 \\
46 \\
50\end{array}$ & $\begin{array}{l}\mathbf{F} \\
\mathbf{F}\end{array}$ & $\begin{array}{l}22 \cdot 8 \\
19 \cdot 9 \\
31 \cdot 0\end{array}$ & $\begin{array}{l}13 \cdot 0 \\
11 \cdot 9 \\
12 \cdot 5\end{array}$ & $\begin{array}{l}56 \cdot 8 \\
59 \cdot 8 \\
40 \cdot 4\end{array}$ & $\begin{array}{l}22 \cdot 7 \\
20 \cdot 9 \\
21 \cdot 8\end{array}$ \\
\hline Mean & $1-10$ & 40 & $3 \mathrm{M} ; 7 \mathrm{~F}$ & $38 \cdot 2$ & $21 \cdot 1$ & $53 \cdot 9$ & $76 \cdot 7$ \\
\hline $\begin{array}{c}\text { Hyperhydroxy- } \\
\text { prolinaemia }\end{array}$ & 11 & 11 & $\mathbf{M}$ & $1,488 \cdot 0$ & $925 \cdot 0$ & $62 \cdot 0$ & $1,610 \cdot 0$ \\
\hline
\end{tabular}


regardless of the actual magnitude of total hydroxyproline excretion. The ratio to total hydroxyproline is unaffected, whether the total hydroxyproline excretion is very high or very low; furthermore, our knowledge of the minor peptides containing hydroxyproline in urine makes it unlikely that these would show any consistent differences between patients and controls, since most of the known peptides are apparently of a random nature.

It is surprising that prolylhydroxyproline is the major urinary metabolite of collagen containing hydroxyproline. The tripeptide glycylprolylhydroxyproline is the major product of the sequence glycylprolylhydroxyproline in collagen when collagenase is used to degrade collagen in the test tube (Schrohenloher, Ogle, and Logan, 1959). Since the bond between the two imino acidsproline and hydroxyproline-is different, however, from the usual peptide bond, it is reasonable that it should be less readily broken during metabolism.
We undertook the present study initially to learn whether this bond was more or less readily split in patients with rheumatic diseases than in controls. Further studies are required to explain the pro- $\frac{O}{\circ}$ duction of prolylhydroxyproline rather than of glycylprolylhydroxyproline in man. For the pre- $\overrightarrow{\vec{F}}$ sent, these studies would seem to indicate that the -0 end-products of the metabolism of collagen are essentially the same in patients with rheumatic diseases as in normal controls.

\section{Summary}

The urinary excretion of prolylhydroxyproline $\vec{\circ}$ was studied in forty patients with rheumatic diseases $\overrightarrow{\vec{H}}$ and compared with that in seventeen normal controls and one case of known hyperhydroxyproli-@ naemia. It was found that there was no significant 0 difference between the two groups, indicating that ${ }^{\circ}$ the end-products of collagen metabolism are the $\vec{i}$ same in both.

\section{REFERENCES}

Benoit, F. L., Theil, G. B., and Watten, N. H. (1963). Metabolism, 12, 1072 (Hydroxyproline excretion in endocrine disease).

Bonadonna, G., Merlino, M. J., Myers, W. P. L., and Sonenberg, J. (1966). New Engl. J. Med., 275, 298 (Urinary hydroxyproline and calcium metabolism in patients with cancer).

Hosley, H. F., Taft, E. G., Olson, K. B., Gates, S., and Beebe, R. T. (1966). Arch. intern. Med., 118, 565 (Hydroxyproline excretion in malignant neoplastic disease).

Kibrick, A. C., Hashiro, C. Q., Schutz, R. S., Walters, M. I., and Milhorat, A. T. (1964). Clin. chim. Acta, 10, 344 (Prolylhydroxyproline in urine: its determination and observations in muscular dystrophy).

—, Power, H. L., Sevendal, E., and Milhorat, A. T. (1967). Fed. Proc., 26, 779 (Prednisone effect on urinary excretion of hydroxyproline in patients with muscular dystrophy).

,,---1 (In press). Clin. Biochem. (Prolylhydroxyproline in urine: improved method for detecting radio-activity with a scanner on full sheets of chromatography paper).

Laitinen, O., Nikkilä, E. A., and Kivirikko, K. I. (1966). Acta med. scand., 179, 275 (Hydroxyproline in the serum and urine).

Prockop, D. J., and Udenfriend, S. (1960). Analyt. Biochem., 1, 228 (A specific method for the analysis of hydroxyproline in tissues and urine).

Schrohenloher, R. E., Ogle, J. D., and Logan, M. A. (1959). J. biol. Chem., 234, 58 (Two tripeptides from an enzymatic digest of collagen).

Sjoerdsma, A., Davidson, J. D., Udenfriend, S., and Mitoma, C. (1958). Lancet, 2, 994 (Increased excretion of hydroxyproline in Marfan's syndrome).

—, Udenfriend, S., Keiser, H., and LeRoy, E. C. (1965). Ann. intern. Med., 63, 672 (Hydroxyproline and collagen metabolism).

Smiley, J. D., and Ziff, M. (1964). Physiol. Rev., 44, 30 (Urinary hydroxyproline excretion and growth).

Ziff, M., Kibrick, A., Dresner, E., and Gribetz, H. S. (1956). J. clin. Invest., 35, 579 (Excretion of hydroxyproline in patients with rheumatic and non-rheumatic diseases).

L'excrétion urinaire de la prolylhydroxyproline dans les maladies rhumatismales

RÉSUMÉ

L'excrétion urinaire de la prolylhydroxyproline a été etudiée chez quarante malades atteints de maladies rhumatismales et comparée à celle de dix-sept témoins normaux et un cas de hyperhydroxyprolinémie connue. On a trouvé qu'il n'y avait pas une différence marquée entre les deux groupes, indiquant ainsi que les produits finals du métabolisme de collagène étaient les mêmes dans les deux groupes.
Excreción urinaria de prolilhidroxiprolina en enfermedade reumáticas

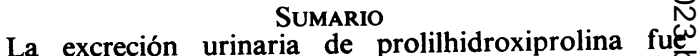
estudiada en cuarenta pacientes con enfermeciades reumáticas y comparada con la de diecisiete controles normales y un caso conocido de hiperhidroxiprolinemiक Se halló que no había diferencia marcada entre los dos grupos, lo que indica que los productos finales del metabolismo de colágeno son iguales en ambos grupos. 